\title{
Students' Socio-Economic Background On Social Media Use In Turkana Central Sub County Kenya
}

\author{
Rose Atoni *, Phillip Ipat *, Paul Ogula * \\ DOI: 10.29322/IJSRP.11.05.2021.p11335 \\ http://dx.doi.org/10.29322/IJSRP.11.05.2021.p11335
}

\begin{abstract}
Social media is becoming an essential tool for professional growth, curriculum planning, and student engagement. This study investigated on the influence of students' socio-economic background on social media use in Turkana Central Sub County. The study was guided by the following research questions; what is the socio-economic background of secondary school students in Turkana Central Sub county Kenya. The study was guided by Media Dependency theory and employed causal comparative design. Stratified simple random sampling was used to get the sample size. Questionnaire was used to collect data. Validity was determined by consulting experts. Test and retest method was used to determine reliability. Data analysis was through the use of frequencies, percentages, means and standard deviation. The hypothesis was tested using ANOVA. The finding was that there is a significant relationship between students' socioeconomic background and use of social media. The study recommends that parents should share with children on negative effect of social media, how it affects behaviour and academic achievements.
\end{abstract}

Index Terms- Students'socio Economic Background; Social Media

\section{INTRODUCTION}

$S^{a}$ ocio-economic status is a definite background variable that represents a feature of the social structure in society. Qakes and Rasi (2003) asserted that it was a fact that in families where the parents were privileged educationally, socially and economically, they promote a higher level of achievement in their offspring. The current move to improve the quality of primary education in Kenya, as evidenced in the launched Kenya Education support programme (KESSP) brings with it not only the need to re-evaluate assessment systems, but also to establish the impact of social economic status on learning outcomes as measured by the pupil's Kenya certificate of primary Education Performance ( G.O.K.,2005). A study by Alisa (2010), in Malaba, Kenya found that the gap in attainment between children from the poorest and richest backgrounds grew particularly fast during the primary school years. According to Kosaretsky et al. (2016), the greatest inequality in educational access in the Russian Federation was observed in the 1990s, where the rising number of educational inequalities was largely determined by the accelerating socioeconomic stratification of the population, as well as significant budget cuts to education.

According to Krieger, Williams and Moss as quoted in the draft report of the Australian Commission on Health (2007); refer to socio- economic position as an aggregate concept that includes both resource-based and prestige-based measures, as linked to both childhood and adult social class position. Moreover, the socio-economic status is another important determinant of internet usage. The studies in the literature indicate that people at a higher socio-economic status tend to use internet more as compare to those at a lower socioeconomic status. People at a higher socioeconomic status are more effective in using internet productively and also for increasing their economic wealth. However socioeconomic status is a multifaceted concept measured through several variables like educational level, employment status and income levels. Here the education level attained and income is strongly correlated. However income has also been found to have an independent effect on internet usage. It is found out that people with high income tend to be involved in using internet for news, for searching jobs, product information and also for work. On the other hand people with low income are found to be more inclined towards using internet for entertainment and downloading (Ritzhaupt, Liu, Dawson, Barron, 2013).

Lucky (2013) described social media as a means of interactions among people in which they create, share, and/or exchange information and ideas in virtual communities and networks. By design, social media is internet-based and gives users quick electronic communication of content. Content includes personal information, documents, videos, and photos. McLoughlin and Lee (2010) stated that using social media networks in the educational process could help educators to apply the inquiry-based approach and encourage the collaboration between the instructor and the students, thereby encourage engagement.

Social network tools afford students and institutions with multiple opportunities to improve learning methods. Through these networks, you can incorporate social media plugins that enable sharing and interaction. Students can benefit from online tutorials and resources that are shared through social networks. There is valuable knowledge to be gained through social media such as analytics and insights on various topics or issues for study purposes. Social media is also a medium where students can establish beneficial connections for their careers. A survey done by Kist (2008) on internet access by teenagers revealed that about 90\% of teenagers in the United States have Internet access, and about seventy-five percent of these teens use the Internet more than once per day. This study also showed that approximately half of all teens who have Internet access are also members of social networking sites, and use the Internet to make plans and socialize with friends. Report of Pew Research Centre (2012) on social networking popular across globe Arab publics most likely to express political views online revealed that in countries such as 
Britain, the United States, Russia, the Czech Republic and Spain, about half of all adults now use Facebook and similar websites. These sites are also popular in many lower-income nations, where, once people have access to the internet, they tend to use it for social networking. Camila, Ibrahim and Dalhatu (2013), indicated that social media has become one of the most influential communication tool which could be effectively used on teaching process. Bedir and Gulcu (2016) argued that teachers and students could effectively discuss and exchange their course related ideas via social media.

\section{THEORETICAL FRAMEWORK}

The study was guided by Media Dependency theory whose proponent is Melvin Defleur (1976). Media dependency theory is a systematic approach to the study of the effects of mass media on audiences and of the interactions between media, audiences, and social systems. Dependency theory conceives of dependency as a relationship in which the fulfilment of one party's needs and goals is reliant on the resources of another party. Dependency theory is a mass communication theory that seeks to explain the long term effects of media on the audiences and a society. This theory states that the more dependent an individual is on the media for having his or her needs fulfilled, the more important the media will be to that person. The central point of the theory is that people in modern society depend on the media to comprehend and understand the world around them. Dependency theory indicates that there is a fundamental connection between media, its audiences and the social system. They assume that since learning from experiences has constraints in practical life, human beings who are largely the audiences rely heavily on media to gather more information about what they need.

\section{METHODOLOGY}

This study used causal-comparative design, that seeks to find relationships between independent and dependent variables after an action or event has already occurred.

\section{Target Population}

The target population constituted all 11 public Secondary Schools and all 5 private secondary schools in Turkana Central Sub County with a total of 5656 students. The Secondary school students were the key respondents in this study because they are the ones using social media and the main targeted study group of this study.

\section{Sample and Sampling Procedures}

Stratified random sampling technique was used.

Research Instruments: The study utilized a Questionnaire to collect the data.

Validity: it was determined using a questionnaire

Reliability : was determined using test retest

\section{Description of Data Analysis}

The collected quantitative data was analysed using descriptive data analysis technique involving frequencies and percentages.

\section{RESULTS}

\section{Socio-Economic background of School Students}

The research question sought to find out students' socioeconomic background which was determined by parents occupation and level of education and the results are displayed in Table 1:

Table 1: Frequencies and Percentages Distribution of Students Socio-Economic Background

\begin{tabular}{|c|c|c|}
\hline Variables & $\mathbf{F}$ & $\%$ \\
\hline Farmers/ Pastoralist Class & 54 & 24.0 \\
\hline Working/Business class & 89 & 39.5 \\
\hline Middle class & 43 & 19.1 \\
\hline Professionals class & 39 & 17.4 \\
\hline Total & 225 & 100 \\
\hline
\end{tabular}

Table 1 shows that Professional class of sampled parents were $39(17.4 \%)$, middle class 43(19.1\%), working or Business class $89(39.5 \%)$, while the peasant/pastoralist were 54(24.0\%). This is an indication that most of the parents are not professionals or have limited training. The Turkana County is one of the marginalised counties hence its economy is very low hence major businesses are low level businesses in the villages.

In respect to the level of education professionals have degrees while middle class have diplomas and certificates making only $82(36 \%)$ of the parents in Turkana Central sub county have attained above secondary education. Below the secondary level parents some of them might have dropped out of school due to pregnancies, indiscipline, lack of fees, hence the percentage of those with better education is low. The rest of the parents have either dropped out of primary school or they have not gone to school. Some the professionals and middle class with recognized certificates are not employed may be due low absorption rate. This shows that there is high rate of unemployment in the County. The findings are in agreement with Turkana County Integrated Development Plan (CIDP II, 2018-2022), stipulates that, the county is faced with high dropout rates and low transition rates from primary to secondary school as well as from secondary school to tertiary institutions.

\section{Students Use Social Media}

The research sought to find out the extent which students use social media. The responses of participants is displayed in Table 2: 
Table 2: Frequencies and Percentages Distribution of Social Media Use

\begin{tabular}{|c|c|c|c|c|c|c|c|c|c|}
\hline \multirow[b]{3}{*}{ Variables } & \multirow[b]{2}{*}{ Never } & \multirow{2}{*}{\multicolumn{2}{|c|}{ Rarely }} & \multirow{2}{*}{\multicolumn{2}{|c|}{ Sometimes }} & \multirow{2}{*}{\multicolumn{2}{|c|}{ Often }} & \multicolumn{2}{|c|}{ Very often } \\
\hline & & & & & & & & & \\
\hline & $\%$ & $\mathrm{f}$ & $\%$ & $\mathrm{f}$ & $\%$ & $\mathrm{f}$ & $\%$ & $\mathrm{f}$ & $\%$ \\
\hline \multirow[t]{2}{*}{ I use whatsApp to chat with friends } & 22.2 & 10 & 4.4 & 56 & 24.9 & 14 & 6.2 & 8 & 3.6 \\
\hline & 11.1 & 8 & 3.5 & 37 & 16.4 & 12 & & 5.35 & 2.2 \\
\hline I use Google search to do myM 72 & 32 & 38 & 16.9 & 10 & 4.4 & 9 & 4 & 9 & 4 \\
\hline assignment & 25.3 & 10 & 4.4 & 8 & 3.6 & 6 & 2.7 & 6 & 2.7 \\
\hline $\begin{array}{l}\text { I always send short messages to myM } 30 \\
\text { friends using a smart phone }\end{array}$ & 13.3 & 16 & 7.1 & 58 & 25.8 & 24 & 10.7 & 15 & 6.7 \\
\hline F 18 & 8 & 14 & 6.2 & 25 & 11.1 & 17 & 7.6 & 8 & 3.6 \\
\hline I make calls to my friends after schoolM 56 & 24.9 & 12 & 5.3 & 53 & 23.6 & 5 & 2.2 & 12 & 5.3 \\
\hline F 39 & 17.3 & 6 & 2.7 & 30 & 13.3 & 6 & 2.7 & 6 & 2.7 \\
\hline \multirow[t]{2}{*}{ I have a group in twitter } & 48.4 & 9 & 4 & 8 & 3.6 & 3 & 1.3 & 9 & 4 \\
\hline & 27.1 & 6 & 2.7 & 10 & 4.4 & 4 & 1.8 & 6 & 2.7 \\
\hline I always update my status in FacebookM 78 & 34.7 & 19 & 8.4 & 29 & 12.9 & 9 & 4 & 3 & 1.3 \\
\hline F 42 & 18.7 & 15 & 6.7 & 21 & 9.3 & 8 & & 3.61 & 0.4 \\
\hline I share with my friends photos throughM 76 & 33.8 & 14 & 6.2 & 20 & 8.9 & 11 & 4.9 & 15 & 6.7 \\
\hline instagram & 2.9 & 9 & 4 & 18 & 8 & 4 & & 1.811 & 4.9 \\
\hline \multirow{2}{*}{$\begin{array}{l}\text { I usually watch videos through youM } 56 \\
\text { tube } \\
\text { F } 27\end{array}$} & 24.9 & 34 & 15.1 & 23 & 10.2 & 19 & 8.4 & 16 & 7.1 \\
\hline & 12 & 17 & 7.6 & 15 & 6.7 & 11 & & 4.97 & 3.1 \\
\hline \multirow{4}{*}{$\begin{array}{l}\text { I send photos and videos to friends byM } 70 \\
\text { snap chat } \\
\begin{array}{ll}\text { I always send emails to my friendM } 85 \\
\text { when i'm free } & \text { F } 55\end{array}\end{array}$} & 31.1 & 4 & 1.8 & 35 & 15.6 & 14 & 6.2 & 15 & 6.7 \\
\hline & 24.4 & 2 & 0.9 & 18 & 8 & 9 & 4 & 3 & 1.3 \\
\hline & 35.6 & 7 & 3.1 & 38 & 16.9 & 2 & 0.09 & 11 & 4.9 \\
\hline & 24.4 & 8 & 3.6 & 15 & 6.7 & 2 & & 0.097 & 3.1 \\
\hline 225 & & & & & & & & & \\
\hline
\end{tabular}

According to Table 2, students in Turkana central Sub County use social media rarely. The findings show that students have social media gadgets as they sometimes send short messages to their friends after school hours. They are therefore access to network. The results show that students have low usage of twitter, moderate usage of Google, Facebook, Instagram, Snap chat and emails. Usage of WhatsApp, making calls and you tube is high while the rate at which students send short messages is very high. The above results also concur with outcome of Kiplagat and
Ombiro (2016) study that revealed majority of students in day secondary school were aware and access to social media sites with majority of them spending an average of over two hours per day. The most frequented social sites being What'sApp and Facebook and teachers, students and principals strongly agreed that access to social media sites by high school students has affected negatively their academic and language usage.

Table 3: Mean Scores(MS) and Standard Deviation(SD) of Social Media Use

\begin{tabular}{llll}
\hline Variables & & MS & SD \\
\hline Gender & Male & 21.5 & 2.808 \\
& Female & 28.3 & 3.476 \\
School Category & Public & 15.0 & 2.977 \\
& Private & 27.5 & 4.609 \\
School Type & Boarding & 17.4 & 3.976 \\
& Day & 30.3 & 4.978 \\
School Location & Day/Boarding & 21.5 & 3.407 \\
& Urban & 14.5 & 3.327 \\
\multirow{3}{*}{ Students Age } & Periphery-Urban & 27.4 & 5.825 \\
& Rural & 15.5 & 5.668 \\
& $16-17$ years & 18.4 & 7.387 \\
& $18-19$ years & 19.7 & 2.952
\end{tabular}




\begin{tabular}{lccc} 
& $20-21$ years & 28.2 & 3.993 \\
Students & Socio-economicFarmers/ Pastoralist Class & 16.2 & 5.198 \\
Background & Working/Business class & 26.7 & 3.383 \\
& Middle class & 25.0 & 4.883 \\
& Professionals class & 30.4 & 5.429 \\
\hline
\end{tabular}

In reference to Table 3 female students have high mean score 28.3 than male students 21.5; private schools have high mean score 27.5 which spreads out over a wider range than public schools with 15.0 mean score. Day schools have high mean score, 30.3 compared to boarding and partial schools. Periphery-urban schools students have high mean score, 27.4 compared to other to students in schools in other location but they have wider variation in use of social media as indicated by standard deviation 5.825 . Students between 20 to 21years have high mean score, 28.3 compared to other years though students of between 16 to 17 years have a wider variation of social media usage. Professional class students have high mean score compared to other classes but there is a minimal difference in their standard deviation.

Based on Table 3 female students use social media more than male students. Day schools students have higher level of social media compared to Boarding and partial schools students. The results also show that periphery-urban schools use social media more than other schools. The older students in secondary schools of above 20 years have higher usage of social media compared to other ages. There is a relationship between the demographic characteristics and use of social media

Based on mean scores and standard deviation in Table 3 students from professional class use all types of social media tested hence have high mean score of 30.4. May be the students from such families are fewer as some parents might have taken their children to better schools outside the county or parents control usage of social media by their children since they know its impact. Students from middle or working/ Business class use all types of social media sometimes except Google that they use rarely and short messages that they send often as their mean scores are too close and their SDs with insignificant difference. They therefore use all types of social media. According to the Table students from farmers and pastoralist class never or rarely use social media as their mean score is low as 16.2. The results above agree with Adeboye (2017) findings that, there is significant relationship between socio-economic status and use of social media as the students' socio-economic status increase, their use of social media networks also improves. This implies that the use of social media by students may be dictated by parenting style and students discipline.

The results concurs with Heinz (2016) observations, that children from lower socio-economic background appear to have unlimited and unmonitored access to the internet. Only parents from higher socio-economic backgrounds are perceived by teachers as guiding their children in using ICT and acquiring digital competencies. Students from professional and middle class may be privileged to have social media gadgets compared to those from pastoralist and self-employed class since the lower class parents struggle to ensure children have basic needs as the social media gadgets are luxury to them. The use of social media therefore will vary depending with the parental class and parenting style. The results concur with Adeboye (2017) findings that as socio-economic status of the respondents improves, there is tendency for increased use of social media. Therefore, there is a significant difference between mean of social media scores of students from different socio-economic background. Student's access to funds and provision of technological equipment by parents and caregivers may influence their excessive use of computers and in turn, social media use.

\section{Students Views on Use of Social Media}

The research sought to find out the students opinion on the right to use social media. an open question that "in your views is it right for students to use social media?" The students views based on their responses of 'Yes' or 'No' were quantified and the frequencies and percentages are presented in Table 4.

\section{Table 4: Frequencies and Percentages Distribution of Students Social Media Views}

\begin{tabular}{llllll}
\hline \multirow{2}{*}{ Variables } & & Yes & \multicolumn{2}{l}{ No } \\
Gender & Male & f & \% & f & \% \\
& Female & 41 & 18.2 & 97 & 43.1 \\
School Category & Public & 56 & 24.9 & 31 & 13.8 \\
& Private & 45 & 20.0 & 93 & 41.3 \\
School Type & Boarding & 52 & 23.1 & 35 & 15.6 \\
& Day & 23 & 10.2 & 28 & 12.4 \\
& Day/Boarding & 47 & 20.9 & 63 & 28.0 \\
School Location & Urban & 27 & 12.0 & 37 & 16.4 \\
& Periphery-Urban & 37 & 16.4 & 43 & 19.1 \\
Students Age & Rural & 31 & 13.8 & 51 & 22.7 \\
& 16-17 years & 29 & 12.9 & 34 & 15.1 \\
& $18-19$ years & 21 & 9.3 & 53 & 23.6 \\
& 20-21 years & 23 & 10.2 & 31 & 13.8 \\
& & 53 & 23.6 & 44 & 19.6
\end{tabular}




\begin{tabular}{|c|c|c|c|c|c|}
\hline \multirow[t]{5}{*}{ Students Socio-economic Background } & Farmers/ Pastoralist Class & 31 & 13.8 & 65 & 28.9 \\
\hline & Working/Business class & 23 & 10.2 & 33 & 14.7 \\
\hline & Middle class & 24 & 10.7 & 19 & 8.4 \\
\hline & Professionals class & 19 & 8.4 & 11 & 4.9 \\
\hline & Total & 97 & 43.1 & 128 & 56.9 \\
\hline
\end{tabular}

According to Table 4 students who said yes it was right for students to use social media were 97(43.1\%). In reference to demographic characteristics distribution, the variables that had yes response and high others include female 56(24.9\%), private schools $52(23.1 \%)$, Day schools 47(20.9\%), urban schools $37(16.4)$, 20-21 years age group 53(23.6\%) and Farmers/Pastoralist class 31(13.8\%) They had at most used rarely the 10 types of social media tested. Their level of usage of social media was low and they had the following views; social media promotes students with a better learning system , that is, a student can Google a question to get an answer. Helps students know what is going on in the country or current affairs outside the country. Social media enables students to learn good moral value. Through social media one can learn good things they never knew before. It's part of learning ( e-learning) enables learners to take lessons in absence of teachers. It promotes on-line learning and revision for students while preparing for national exams. It improves English grammar; students can learn the current spelling of words. Students can socialise with others and improve their socioeconomic lifestyle. Those who agree with the right to use social media had a similar view with Ching (2017) who established that social media plays an important role in students educational life if it was used in a correct and purposive manner.

Based on Table 4 students who said it was not right for students to use social media were $128(56.9 \%)$. The higher groups based on variables were: male $97(43.1 \%)$, public 63(28.0\%), day schools 51(22.7\%), periphery-urban 53(23.6\%), 16-17 years age group $65(28.9 \%)$ and farmers/pastoralist class $65(28.9 \%)$ as compared with others within the same variable. Most of them had used almost all types of social media sometimes, often and very often, except twitter that most of them indicated that they had never used. They had the following views; not all social media items are good to students. Social media will impact negatively on academic performance. Some students fall on a trap and end up losing their lives due to use of internet or social media as they join cults. It promotes drug and substance abuse which is harmful to school going age. It makes students misuse their leisure time; watching pornographic videos promotes bad culture/ immoral behaviour. Social media hampers the education sector; in that those students who like the internet perform poorly in school and play truancy in school. Leads to poor concentration in class. Students imitate poor mode of dressing as they watch movies. Social media is addictive in a bad way generally. It promotes misuse of time by students. It leads to students being abused morally hence must be out-lawed. The views of those students who said it was not right to use social media concur with Mohsen, Ali and Alireza (2019) results that showed that students who used social networks and internet more than average had a poor academic achievement and low level of concentration in the classroom. They also concur with Masood, Ali, Yang and Asma (2017) who had established that despite the various benefits that come with the involvement of school students on social media networks, the results indicated that its misuse could negatively affect the academic performance of the students.

Test of Hypothesis: there is no significant difference between students' socio-economic background mean and social media use scores.

To test hypothesis that, there is no significant difference between students' socio-economic background mean and social media use scores ANOVA was used to test it and results are shown in Table 5:

Table 5: ANOVA Summary for Students' Socio-economic Background and Social Media Scores

\begin{tabular}{llllll}
\hline & Sum of Squares & df & Mean Square & F & Sig. \\
\hline Between Groups & 269.796 & 3 & 89.932 & 207.032 & .000 \\
Within Groups & 95.999 & 221 & .434 & & \\
Total & 365.796 & 224 & & & \\
\hline
\end{tabular}

Since the p-value in Table 5 is less than the significance level of 0.05 the null hypothesis is rejected. There is a relationship between students' socio-economic background and use of social media. The usage of social media varies from students from poor families to rich families. The findings are in agreement with Adeboye (2017) that there is statistically significant association between socio-economic status and use of social media. As socioeconomic status of the respondents improves, there is tendency for increased use of social media

\section{CONCLUSION}

Based on the study findings, the researchers made the following conclusions:

Students' socio-economic background has a significant influence on use of social media by students. Students from middle and professional classes have higher usage of social media compared to those from farmers/pastoralist and business classes.

\section{Recommendations}


The researchers based on findings and conclusion of the study made the following recommendations to the stakeholders;

\section{Parents}

Since most the students are in day schools they can access phones. Parents should therefore help in reducing time spent in chatting agreeing with students on appropriate time to chat. Parents should discourage students on pornographic access and cyber-bullying by creating awareness to students. They should share with children on negative effect of social media, how it affects behaviour and academic achievements.

\section{Kenya Institute of Curriculum Development (KICD)}

The Kenya Institute of Curriculum development functions include; Crafts, reviews, and approves curricula, curriculum support materials, and programs that meet relevant international standards. Since social media and internet access and use as become part of education system, the KICD should incorporate social media use and its gadgets as part of teaching and learning materials. Schools are encouraged to offer computer studies and use online to give returns to the government; students should be allowed to use specific smart phones that can be compatible with lessons.

\section{Students}

Students should only use computers during lesson time or while doing assignment and should be guided to use phones at home during free time and after doing homework. They should be selective about social media information and only use information that is beneficial to them. Students should take instruction from parents and teachers.

\section{Teachers}

Teachers have longer hours with students than parents hence they are on upper hand to create awareness on students' prudent use of social media. Teachers should educate students' on beneficial sites and information on social media that can support their academic achievements. The guidance and counselling committee should understand negative influence of social media and guide students appropriately. The disciplinary committee assist the school administration in management of social media gadgets in school compound to ensure that they are used for academic purposes only.

\section{Principals of Schools}

Principals through the management and supervisory role should provide guideline for usage of any social media in schools. The principal should identify loop holes of entry of phones in school and coordinate with parents and teachers to give guidance those students who are culprits.

\section{REFERENCES}

[1] Adeboye, J., \& Oyeboade,J. (2017). Socio-economic status, peer pressure and use of social media by undergraduate students in university of ibadan, Ibadan, Oyo state, Nigeria

[2] Alisa, G. and Gregg, P. (2010). Poorer Children's Educational Attainment: How Important Are Attitudes.

[3] Bedir, A., \& Gülcü A., (2016). Sosyal medya kullanımının üniversite öğrencilerinin akademik başarılarına ve tutumlarına etkisi. Yüksek Lisans Tezi, Atatürk Üniversitesi, Eğitim Bilimleri Enstitüsü, Bilgisayar Ve Öğretim Teknolojileri Eğitimi Ana Bilim Dali, Erzurum. Retrieved from https://tez.yok.gov.tr/UlusalTezMerkezi/

[4] Kist, W. (2008). Digital literacies:"I gave up MySpace for Lent": New teachers and social networking sites. Journal of Adolescent \& Adult Literacy, 52, 245-247.

[5] Kiplagat, P. (2017). Social Media Usage and Academic Performance in Secondary Schools, Kenya

[6] Ritzhaupt, A. D., Liu, F., Dawson, K., \& Barron, A. E. (2013). Differences in student information and communication technology literacy based on socio-economic status, ethnicity, and gender: Evidence of a digital divide in Florida schools. Journal of Research on Technology in Education, 45, 291307.

\section{AUTHORS}

First Author - Rose Atoni, rose.atoni@yahoo.com Second Author - Phillip Ipat, ipateregae@gmail.com Third Author - Paul Ogula, ogulapaul@gmail.com 